\title{
Currency Unions and Regional Trade Agreements: EMU and EU Effects on Trade
}

\author{
Reuven Glick \\ Federal Reserve Bank of San Francisco
}

October 2016

Working Paper 2016-27

http://www.frbsf.org/economic-research/publications/working-papers/wp2016-27.pdf

\section{Suggested citation:}

Glick, Reuven. 2016. “Currency Unions and Regional Trade Agreements: EMU and EU Effects on Trade" Federal Reserve Bank of San Francisco Working Paper 2016-27. http://www.frbsf.org/economic-research/publications/working-papers/wp2016-27.pdf

The views in this paper are solely the responsibility of the authors and should not be interpreted as reflecting the views of the Federal Reserve Bank of San Francisco or the Board of Governors of the Federal Reserve System. 


\title{
Currency Unions and Regional Trade Agreements: EMU and EU Effects on Trade
}

\section{Reuven Glick*}

Draft: October 6, 2016

\begin{abstract}
The effects of the European Economic and Monetary Union (EMU) and European Union (EU) on trade are separately estimated using an empirical gravity model. Employing a panel approach with both time-varying country and dyadic fixed effects on a large span of data (across both countries and time), it is found that EMU and EU each significantly boosted exports. EMU expanded European trade by $40 \%$ for the original members, while the EU increased trade by almost 70\%. Newer members have experienced even higher trade as a result of joining the EU, but more time is necessary to see the effects of their joining EMU.
\end{abstract}

Keywords: gravity, exports, trade, bilateral, fixed, time-varying, country, currency union, monetary union, agreement, regional, European

JEL Classification codes: F15, F33

\section{Contact:}

Economic Research Department, Federal Reserve Bank of San Francisco

101 Market St., San Francisco CA 94105

Tel: (415) 974-3184

E-mail: reuven.glick@sf.frb.org

URL: www.frbsf.org/economic-research/economists/Reuven-Glick/

* Group Vice President of International Research, Economic Research Department, Federal Reserve Bank of San Francisco. For research assistance, I thank Genevieve Denoeux and Neil Gerstein; for comments on earlier versions of this paper, I thank workshop participants at Claremont McKenna College, the University of California at Santa Cruz, and the $22^{\text {nd }}$ Dubrovnik Economic Conference. The views expressed below do not represent those of the Federal Reserve Bank of San Francisco or the Board of Governors of the Federal Reserve System. The data set used in the paper is available at http://faculty.haas.berkeley.edu/arose. 


\section{Introduction}

There has been considerable disagreement concerning the magnitude of the tradestimulating effect of the Economic and Monetary Union (EMU) in Europe, or indeed of any currency union in which member countries use the same currency. In earlier work, Glick and Rose (2002) estimated how the amount of trade between two countries was affected by whether they were in a currency union. Using a gravity model specification, they explained bilateral trade as a function of the GDP income of the two countries in each pair, the distance between them, and a host of other variables that may facilitate trade, such as sharing a border, a common language, membership in a common regional trade agreement, or a similar colonial history. To this specification, they added a measure of whether or not two countries share a common currency or have a stable one-for-one interchange of their currencies. Using a panel of 200 countries from 1948 to 1997, before the establishment of the EMU, they found that bilateral trade approximately doubled as a pair of countries formed and halved when a currency union dissolved.

The relevance of this estimate for the EMU was questioned on the grounds that it largely reflects the experiences of less developing countries in multilateral currency unions or in "hub and spoke” relations with a large anchor country. In fact, influential papers, such as Micco et. al. (2003), Bun and Klaassen (2007), Baldwin and Taglioni (2007), Baldwin et al. (2008), and Berger and Nitsch (2008) have estimated that EMU improved trade on the order of 15\% or less, much smaller than the estimates in Glick and Rose (2002) suggest.

Glick and Rose (2016) extended their earlier analysis to include the effect of currency unions on international trade through 2013, a period which includes the introduction of the EMU, which began with 11 member countries in 1999 and has since expanded to 19 members. To 
account for the possibility that trade effects for EMU countries may differ from that for other currency unions, which typically involve a developing country, they distinguished between the trade effects of EMU and non-EMU currency union pairs. They also made use of advances in econometric methodology. ${ }^{1}$ Their preferred methodology - a panel approach with both dyadic and time-varying exporter and importer fixed effects on a long broad data set -led them to conclude that the effect of EMU on intra-European trade was still substantive, on the order of $50 \% .^{2}$

Of course, European trade has been affected by other efforts to foster regional economic integration, notably the elimination of tariffs and quotas and implementation of free trade arrangements through membership in the European Union (EU), which preceded establishment of the EMU. Since EU membership is a prerequisite for joining EMU, it is reasonable to make efforts to disentangle the effects of integration through adoption of a common currency and through regional trade arrangements. In their earlier work Glick and Rose (2002, 2016) controlled for membership in regional trade arrangements through inclusion of an aggregated measure that captures the average effect of all regional trade agreements (RTAs). However, by aggregating all such arrangements together they do not allow for possible heterogeneity in the effects of different arrangements, such as the EU. This paper specifically distinguishes between

\footnotetext{
${ }^{1}$ For recent methodological work on the estimation of gravity models, see the important contribution of Anderson and van Wincoop (2003) and the literature surveys in Baldwin and Taglioni (2007) and Head and Mayer (2014).

${ }^{2}$ Glick and Rose (2016) also tested whether symmetry between currency union entry and exit is justified in the data. Since the data set of their EER (2002) paper included only 16 switches into, but 130 switches out of, currency unions before 1998, they explicitly assumed symmetry between entries and exits when making inferences about the trade effects of entry. Since the many entries into EMU provide a non-trivial number of observations of currency union entries, they were able to formally check this assumption and found it could not be rejected.
} 
the separate effects of EU and other RTAs so as to explicitly analyze how membership in EU affects the trade effects of EMU.

The paper also assesses the extent to which the effects of EMU and EU on trade flows differ between older and newer members. As shown in Table 1, the present-day EU is the result of increasing trade and other economic integration through successive enlargements since the 1950s. The original six members - Belgium, France, (West) Germany, Italy, Luxembourg, and the Netherlands - created the European Economic Community (EEC) in $1958 .{ }^{3}$ The first enlargement occurred in 1973 when the United Kingdom, Ireland, and Denmark joined. Greece followed in 1981, Portugal and Spain in 1986. Austria, Finland, and Sweden became members in 1995 of the renamed European Community (EC), later branded as the European Union (EU). By far the biggest enlargement took place in May 2004 when 10 more countries -- Cyprus, Czech Republic, Estonia, Latvia, Lithuania, Hungary, Malta, Poland, Slovakia, and Slovenia -all became members. Bulgaria and Romania followed in 2007, and the newest member, Croatia, joined in $2013 .{ }^{4}$

Thirteen, roughly half, of the current membership of the EU joined after 2003. Thus far, seven of these thirteen countries have also joined EMU. As most of these newer members are transition economies that differed significantly from the original members in terms of their economic structure and development, there is reason to believe that the impact of EU and EMU entry might differ as well. Moreover, of those who subsequently joined the EMU, beginning

\footnotetext{
${ }^{3}$ Some date 1951, when the six original EEC members established the European Coal and Steel Community, as the beginning of the European integration process.

${ }^{4}$ Greenland joined the EC with Denmark in 1973, but left in 1985 after achieving a modicum of self-rule. More recently, in June 2016 the United Kingdom expressed its intention to exit the EU.
} 
with Slovenia in 2007, the experience with the euro is still relatively short. How much the timing of entry affects trade is also investigated. ${ }^{5}$

To preview the conclusions: (i) EMU has a strong positive effect in stimulating trade; (ii) EU also has a strong effect on trade; and (iii) the EMU and EU effects are still strong after separating out the effects for old and new members. With the preferred methodology - a panel approach with both dyadic and time-varying exporter and importer fixed effects on a long broad data set - EMU expands European trade by $40 \%$ for the original members, while the EU increased trade by almost 70\%. Newer members have experienced even higher trade as a result of joining the EU, but more time is necessary to see the effects of their joining EMU.

The paper is organized as follows. Section 2 describes the methodology and dataset. Section 3 reports results for the effect of EMU and other currency unions on trade. Here, as in the earlier work of Glick and Rose (2002, 2016), the analysis starts with a single aggregate indicator dummy that captures the average effect of RTAs on trade flows. Thereafter, the effects of the regional trade agreement variable are disaggregated, so as to separate out the effects of EU membership from those of other trade arrangements. The trade effects of old vs. new members of EMU and EU are also separately estimated EU. Section 4 concludes.

\section{Methodology and Data Set}

To measure the effect of currency unions on aggregate international trade, the analysis starts with estimation of a traditional gravity model of international trade:

$$
\ln \left(\mathrm{X}_{\mathrm{ijt}}\right)=\gamma \mathrm{CU}_{\mathrm{ijt}}+\tau \mathrm{RTA}_{\mathrm{ijt}}+\beta \mathrm{Z}_{\mathrm{ijt}}+\left\{\delta_{\mathrm{t}}\right\}+\varepsilon_{\mathrm{ijt}}
$$

\footnotetext{
${ }^{5}$ Other papers seek to understand the trade effects of RTAs and more general trade arrangements such as the WTO
} (Rose, 2004; Subramanian and Wei, 2007; Eicher and Henn, 2011). 
where $\mathrm{i}$ and $\mathrm{j}$ denote countries, $\mathrm{t}$ denotes time, and

- $\mathrm{X}_{\mathrm{ijt}}$ denotes the real value of bilateral exports from $\mathrm{i}$ to $\mathrm{j}$ at time $\mathrm{t}$,

- $\quad \mathrm{CU}$ is unity if $\mathrm{i}$ and $\mathrm{j}$ use the same currency at time $\mathrm{t}$ and 0 otherwise,

- $\quad$ RTA is unity if $\mathrm{i}$ and $\mathrm{j}$ belong to the same regional trade arrangement at time $\mathrm{t}$ and 0 otherwise,

- $\quad \beta$ is a vector of coefficients,

- $\mathrm{Z}$ is a vector of controls,

- $\{\delta\}$ is a set of year-specific effects,

- $\varepsilon_{\mathrm{ij}}$ represents the myriad other influences, assumed to be well behaved.

A standard collection of determinants from the gravity literature are used as (Z) controls: the products of national real GDP and real GDP per capita, the distance between the countries, the product of national land masses, dummy variables for the number of landlocked and island countries in the dyad, and dummy variables if the countries share a common language, land border, and (variants of) colonial heritage. $\delta$ controls for the effects at time $t$ that are common to all country pairs.

The coefficients of interest are $\gamma$ and $\tau$, which represent the partial trade impact of currency union and regional trade agreements, respectively. This specification ignores two related phenomena which may affect the impact of currency union and RTA on trade: (i) effects of these forms of integration between $\mathrm{i}$ and $\mathrm{j}$ on other countries through so-called "multilateral resistance" effects; and (ii) general equilibrium effects on spending and output for all countries (see Anderson and van Wincoop, 2003; Baier and Bergstrand, 2009; and Head and Mayer, 2014).

To address these issues a second specification is estimated:

$$
\ln \left(\mathrm{X}_{\mathrm{ijt}}\right)=\gamma \mathrm{CU}_{\mathrm{ijt}}+\tau \mathrm{RTA}+\beta \mathrm{Z}_{\mathrm{ijt}}+\left\{\lambda_{\mathrm{it}}\right\}+\left\{\psi_{\mathrm{jt}}\right\}+\varepsilon_{\mathrm{ijt}}
$$


where

- $\left\{\lambda_{\mathrm{it}}\right\}$ is a complete set of time-varying exporter dummy variables, and

- $\left\{\psi_{\mathrm{jt}}\right\}$ is a complete set of time-varying importer dummy variables,

Since $\left\{\lambda_{\mathrm{it}}\right\},\left\{\psi_{\mathrm{jt}}\right\}$ control for the effects which are specific to a country and all of its trading partners at time t, this equation holds constant all country-specific “monadic" phenomena rather than time-invariant dyadic phenomena. ${ }^{6}$ Consequently, (2) can only estimate the effect of pairspecific phenomena, like the currency union and trade agreement effects on exports.

Neither of these specifications address the issue of omitted variables which is particularly relevant in light of the inherent challenge of including all relevant determinants of bilateral trading relationships. As emphasized by Baldwin and Taglioni (2007) and demonstrated in Glick and Rose (2002, 2016), controlling for unobserved factors by the inclusion of country-pair fixed effects has a significant effect on results. ${ }^{7}$ This is shown to be the case in the analysis later.

\section{The Data Set}

A large data set is used in the analysis in order to obtain sufficient degrees of freedom necessary for inclusion of the many fixed effects required to control for unobservables. A large data set also allows direct comparison of the effects of individual currency unions and trade areas, such as the EMU and EU, with others.

\footnotetext{
${ }^{6}$ These monadic phenomena may be time-invariant (such as land area), or time-varying (such as GDP or “multilateral resistance” to trade).

${ }^{7}$ Baldwin and Taglioni (2007) label the omission of country-pair fixed effects the "gold medal of classic gravity model mistakes.”
} 
The data set used is identical to that assembled by Glick and Rose (2016). The trade data are drawn from the International Monetary Fund (IMF) Direction of Trade and covers bilateral trade between over 200 IMF country codes between 1948 and 2013 (with gaps). ${ }^{8}$ Bilateral trade on FOB exports and CIF imports is recorded in U.S. dollars. ${ }^{9}$ These data are deflated by the U.S. CPI. ${ }^{10}$ Data on population and real GDP (in constant dollars) is obtained from World Development Indicators, supplemented where necessary by the Penn World Table Mark 7.1, and the IMF's International Financial Statistics. The CIA's World Factbook is used for a number of country-specific variables such as latitude and longitude, land area, landlocked and island status, common borders, language, colonizers, and dates of independence.

As in Glick and Rose (2002,2016), the currency union variable is defined as country pairs using the same money or where currencies are interchangeable between the two countries at a 1:1 par for an extended period of time, so that there was no need to convert prices when trading bilaterally; EMU is by far the most important contemporary example. ${ }^{11}$ Hard fixes (such as those of Hong Kong or Denmark) do not qualify as currency unions under this definition. The

\footnotetext{
${ }^{8}$ Not all of the areas covered are countries in the conventional sense of the word; colonies (e.g., Gibraltar), territories (e.g., Guam), overseas departments (e.g., Guadeloupe), countries that gained their independence during the sample (e.g., Guinea-Bissau), and so forth are all included. The countries in the sample are listed in an appendix available online at http://faculty.haas.berkeley.edu/arose.

${ }^{9}$ More specifically, exports from $i$ to $j$ are measured as the average of the nominal value of exports from $i$ to $j$ and imports by j from I when both are available. Glick and Rose $(2002,2016)$ also report results using (log) average trade as the dependent variable, where average trade is measured as the average value of the nominal value of bilateral trade between a pair of countries, calculated by averaging all of the four possible measures potentially available.

${ }^{10}$ The series are indexed to $2005=100$. The results are not affected if the data are left in nominal U.S. dollars, allowing the year dummies to pick up the price effects.

${ }^{11}$ More precisely, the dummy variable $\mathrm{EMU}_{\mathrm{ijt}}$ equals one if both $\mathrm{i}$ and $\mathrm{j}$ use the Euro at time $\mathrm{t}$, and zero otherwise. This variable is constructed similarly to that of the more general currency union variable but restricts it to countries that use the Euro, including EMU member countries as well as overseas Departments of France (Guadeloupe, French Guiana, Martinique, St. Pierre \& Miquelon, Reunion), Montenegro, and Kosovo.
} 
definition of currency union is transitive; if dyads $x-y$, and $x-z$ are in currency unions, then $y-z$ is a currency union.

The World Trade Organization’s website provides data on regional trade agreements. The constructed European Union (EU) variable includes its predecessor arrangements such as the European Economic Community (EEC) and European Community (EC). ${ }^{12}$

\section{Estimation Results}

The analysis begins with estimation of (1) with ordinary least squares, using standard errors robust to clustering (since dyads [country-pairs] are dependent across years).

\subsection{Pooled panel}

Pooled panel estimates for (1) are presented in the first two columns of Table 2. As shown in the first column, the point estimate of $\gamma$ is .90 with a (robust) standard error of .08, implying exports rise by more than $200 \%\left(\mathrm{e}^{.90} \approx 2.46\right)$. In the second column of Table 2 , the EMU effect is separated out from the combined effects of all other currency unions to see if the trade effects of EMU differ from those of other unions. The effect for non-EMU unions rises somewhat to 1.07, but the effect of EMU membership is much lower in economic terms (.19), though still significant. This implies that EMU has a substantively different effect on trade than other monetary unions. All of the other coefficients have the expected signs, including the RTA coefficient $\tau$ which has a value of 1.0 , similar in magnitude to the effect of CUs. ${ }^{13}$

\footnotetext{
${ }^{12}$ In addition to the countries listed in Table 1, the EU dummy also includes overseas French Departments.

${ }^{13}$ Glick and Rose (2016) obtain similar results for the effects of EMU using the log of average trade, rather than exports, as the dependent report. However, they do not report the coefficients for RTAs or other gravity model variables.
} 
As emphasized in Glick and Rose (2002, 2016), it is important to account for all countrypair effects, whether observable or not, including potential endogeneity of currency unions. In addition, since within estimator relies only on time-series variation around pair means, it answers the policy question of interest, namely the (time series) question "What is the trade effect of a country joining (or leaving) a currency union?” For these reasons, estimates that include dyadic fixed effects are preferred. ${ }^{14}$

Accordingly, (1) is re-estimated with the inclusion of (more than 28,000) dyadic fixed effects. The resulting (within) estimates are presented in the last two columns of Table 2. These estimates rely only on time-series variation around dyadic means, and thus account for all country-pair effects, whether observable or not. Since such dyadic effects are very significant in both statistical and economic terms, the within estimates of Table 2 should be considered to be much more believable than those given in the first two columns of Table 2 .

The estimates in Table 2 indicate that the within estimate of $\gamma$ is lower than the pooled effect without pair effects, falling from .90 to .61. However, when the EMU effect is split off, the effect for non-EMU currency unions rises to .71, while the EMU effect is now estimated to be large, positive, and significant, with a point estimate of .46 implying that EMU entry expands exports by $\left(\mathrm{e}^{.46}-1 \approx\right) 58 \% .{ }^{15}{ }^{16}$ In addition, observe that including pair fixed effects also lowers

\footnotetext{
${ }^{14}$ It should be noted that the analysis does not claim that currency unions are formed exogenously. Nor does it attempt to find instrumental variables to handle any potential endogeneity problem. The inclusion of pair effects provides an effort to handle this concern.

${ }^{15}$ Glick and Rose (2016), when using (log) trade, rather than exports, as the dependent variable, find an EMU coefficient of .41.

${ }^{16}$ Glick and Rose (2016) report similar results and find that they are not affected if the non-EMU currency union "catch-all” variable is disaggregated into a number of separate currency unions, including the CFA franc zone; the East Caribbean Currency Union, and pairs in which both countries use the Australian \$; the British pound; the French Franc (before the Euro was created); the Indian rupee; and the US \$.
} 
the effect of RTAs, from 1.0 to .37; the decline is comparable after separating out the EMU effect.

\subsection{Results with country-year effects}

How are the results affected by econometric concerns about multilateral resistance and other general equilibrium effects? As discussed above, these concerns are addressed by estimating specification (2) of the gravity equation, which includes time-varying country dummies, with robust standard errors. Table 3 shows the results. ${ }^{17}$

The estimate of $\gamma$ presented in column (1) of Table 3 is economically and statistically significant. The point estimate of the currency union effect on exports is .51. This is a large effect in economic ( $\mathrm{e}^{.51}-1 \approx 67 \%$ ) and statistical terms (the $t$-ratio exceeds 20 ). Point estimates for the other coefficients also seem intuitive in sign and size.

The analysis presented above suggests that EMU may have a different export effect than other currency unions. The effects of EMU are split off in model specification (2); the estimates are presented in col. (2) in Table 3. Consistent with earlier results but even more dramatically, the export-stimulating effect of EMU is lower than other currency unions. While other currency unions now seem to raise exports significantly ( $\mathrm{e}^{.76}-1 \approx 114 \%$, with a $t$-ratio of 38 ), the net effect of EMU on exports is negative; the point estimate is -.65 with a standard error of .03 . This seems extremely implausible.

\footnotetext{
${ }^{17}$ The currency union effects reported in Table 3 are identical to those in Glick and Rose (Table 5, 2016), but the latter do not report the coefficient estimates for any of the other gravity variables, notably regional trade agreements, in (1).
} 
As reported in col. (3), adding country-pair fixed effects (to the time-varying exporter/importer effects) reduces the combined currency union effect somewhat, though it remains positive and significant. However, as shown in col. (4), the EMU effect on exports is now positive and economically significant ( $\mathrm{e}^{43}-1 \approx$ ) 54\% (with a t-ratio exceeding 20 ). Thus, the dyadic effects add considerable explanatory power to the exports equation while reversing the negative EMU effect. Indeed, the point estimate of the EMU effect on exports from Table 3 (with dyadic fixed effects as well as country-year effects), .43, is very similar to the effect (with pair fixed effects alone) from Table 2, col. (4) of .46. ${ }^{18}$

The regressions also show that including pair fixed effects reduces the average effect of RTAs, from .60 in col. (2) to .39 in col. (4) of Table 3, similar to the fixed effect estimate (without country-year dummies) reported in Table 2, col. (4). ${ }^{19}$

The preferred results in Table 4 with dyadic fixed effects deliver an EMU effect which is significantly positive in both the economic and statistical senses. This contrasts with the small and insignificant effects estimated, for example, by Baldwin and Taglioni (2007) and Baldwin et al. (2008), who use a similar specification with country-year dummies and dyadic fixed effects. ${ }^{20}$ Glick and Rose (2016) show that the main reason is the span of the data set across both countries and time. Their analysis as well as the estimates here use 879,794 observations over the period

\footnotetext{
${ }^{18}$ Glick and Rose (2016) show that the $\gamma$ estimates are robust to disaggregating the non-EMU currency union variable as well as to various exercises, including dropping all industrial countries, dropping all small countries, dropping all poor countries, retaining only similarly-sized country-pairs; dropping pre-1960 data, dropping pre-1980 data, and dropping post-2006 data. The EMU coefficients remain significantly positive in both economic and statistical terms and vary little from the default estimate of .43.

${ }^{19}$ Eicher and Henn (2011) also find that including country-pair fixed effects lowers the trade effects of WTO and/or RTA membership.

${ }^{20}$ See the citations in Glick and Rose (2016) as well as in Head and Mayer (2014).
} 
1948-2013; Baldwin and co-authors work with a small sample of industrial countries, , and a much shorter time span, conventional for the EMU-focused literature. Table 5 of Baldwin and Taglioni (2007) reports use of only 4837 observations, while Baldwin et al. (2008) use even less.

\subsection{Disaggregating the RTA effect}

The finding that currency unions in general and EMU in particular have significant trade effects accords with the results in Glick and Rose (2016). However, the regional trade agreement variable included in their analysis as well in the estimation here thus far constrains the effects to be the same across individual RTAs. Table 4 shows what happens when heterogeneity is allowed across RTAs as well as CUs using different econometric specifications.

Focusing on the specifications with country pair fixed effects in col. (2) and (4) of Table 4, observe that the effect of EU is much higher than that of other RTAs. For example, as shown in col. (2) with country-pair effects, but no country-year effects, the EU effect increases exports by (e.86 $-1 \approx) 136 \%$, compared with (e.29 $-1 \approx)$ 34\% for other RTAs. The effects including countryyear effects as well, reported in col. (4), are virtually the same. ${ }^{21}$ The trade effects of EU, (e.94 $1 \approx)$ 156\%, are much larger than those of other RTAs, $\left(\mathrm{e}^{.30}-1 \approx\right) 35 \% .^{22}$

The estimated EU effect are consistent with the findings of others. For example, Carrerre (2006) estimates a gravity model over period 1962-96 with 130 countries with pair effects and year dummies and obtains an EU coefficient of .71, implying trade expansion of 103\%. Baier et

\footnotetext{
${ }^{21}$ Several papers examine the effect of GATT/WTO membership on trade using gravity models (Rose, 2004; Subramanian and Wei, 2007; Eicher and Henn, 2011). The latter particularly stress the importance of including pair fixed effects; doing so, they find that WTO has no significant effect on trade, while regional trade agreements do.

${ }^{22}$ The effects of non-EU RTAs are themselves heterogeneous, but disaggregating non-EU RTAs does not affect the EU results on which the analysis focuses.
} 
al. (2008) control for multilateral resistance effects in a sample of almost 100 countries over the period 1960-2000 and find that EU increased members' trade by $143 \%{ }^{23}$

However, separating out the effects of EU appears to come at a "cost" of significantly reducing the estimated export effects of EMU. Recall the preferred specification in col. (4) of Table 3 using both pair and country-year effects yielded an EMU $\gamma$ coefficient of .43. Allowing heterogeneous RTA effects significantly reduces the EMU effect, to .11, implying a trade increase of only $12 \%$. Evidently, some of the effects of monetary integration reported in Sections 3.1 and 3.2 partially reflected the effects of trade and other forms of integration associated with EU membership. This relatively small estimated effect of EMU when controlling for EU membership is consistent with the results of some of the literature mentioned earlier.

\subsection{Disaggregating old and new members}

Is that the end of the story? No. EMU countries differ significantly in how long since they adopted the euro. In particular, 7 of the current 19 members of EMU only adopted the euro in 2007 or later. Slovenia joined in 2007, Cyprus and Malta in 2008, Slovakia in 2009, and Estonia in 2011, while Latvia and Lithuania adopted the Euro after 2013, the end of the sample. Thus, there are at most 6 years of data for the trade effects of EMUs for new members to manifest themselves. In fact, Glick and Rose (2016) estimate a dynamic specification of the gravity equation with leads and lags of entry and find that the effects of adopting the euro grow

\footnotetext{
${ }^{23}$ Several other papers obtain somewhat smaller, though still quite significant, effects. Eicher and Henn (2008) estimate with pair and country year dummies using a panel of data for 177 countries at 5 year intervals over the period 1950-2000, obtaining a EU $\tau$-coefficient of .31 (Table 2, col. 12). Gil et al. (2008) estimate a gravity model for OECD countries over the period 1950-2004 with pair and country-year effects and obtain an EU $\tau$-coefficient of .49. Bussière et al. (2005) estimate a gravity model with pair effects and find EU membership has a small and insignificant effect on trade in a sample of 61 countries over the period 1980-2003. This small effect can be attributed to the fact that most countries who joined the EU did so before the start of their sample in 1980.
} 
over time. In addition, these countries were generally much less integrated economically with the other older EMU members, particularly as they all joined the EU in 2004 or later.

To investigate this further, Table 5 reports results distinguishing between the EMU and EU effects for “old” (who joined pre-2004) and “new” (who joined in 2004 and later) members of the EMU. More specifically, it separates out the effects on trade among old country pairs (“Old-Old”) and trade involving newer members both among themselves and with older members (“New”). Analogous measures are constructed for EU membership. The preferred specification given by (2) with both country-year and pair fixed effects is employed.

For comparison, the first column of Table 5 reproduces the results in Table 3, separating out the effects of EMU and EU from other arrangements. Breaking out EMU entry by date of membership in col. (2) results in a considerable difference in the trade effect for older and newer members, with a large and very significant effect for the latter and a much smaller effect for the former. However, this result reverses upon allowing heterogeneity in the EU effect. As shown in col. (3), trade among the old members rises by $\left(\mathrm{e}^{.34}-1 \approx\right) 40 \%$, while the effect for new countries is basically zero. The reason is that the trade effects of joining the EU are more than three times as big for the newer as for older members ( $\tau=1.36$ vs. .52, implying $290 \%$ vs $68 \%$ greater exports). Evidently, imposing homogeneity on the effects of EU forces the data to wrongly attribute the effects of EU for the newer members to EMU. Allowing heterogeneity in the EU effect, reveals that EMU indeed has a strong export effect for the older members.

\section{Summary and Conclusion}

In their EER (2016) paper, using annual data that covers more than 200 countries between 1948 and 2013, Glick and Rose concluded that “our preferred methodology (a panel 
approach which includes country-pair fixed effects on the largest possible span of data across countries and time) leads to the conclusion that EMU has thus far boosted bilateral trade by around 50\%.”

In this earlier work membership in regional trade arrangements was controlled through inclusion of an aggregated measure that reflects the average effect of all regional trade agreements (RTAs). However, aggregating all such arrangements together does not allow for possible heterogeneity in the effects of different arrangements, such as the EU. This paper specifically distinguishes between the effects of EU and other RTAs so as to explicitly analyze how membership in EU affects the trade effects of EMU. The extent to which the effects of EMU and EU on trade flows differ between older and newer members is also assessed. As most of these newer members are transition economies that differed significantly from the original members in terms of their economic structure and development, there is reason to believe that the impact of EC and EMU entry might differ as well.

Indeed, breaking out EMU entry by date of membership shows there is considerable difference in the EMU trade effect for older and newer members, with a large and very significant effect for the former. The least squares panel results with time-varying country and dyadic fixed effects, which can be considered to be the most plausible econometric model, deliver large positive effects for the effect of EMU membership on exports of $40 \%$ for the older EMU members. More time is necessary to see the effects of the joining EMU for the newer members. It also found that there are independently significant effects of joining the EU, ranging from $70 \%$ for the older members to almost 300\% for newer members. 


\section{References}

Anderson, James E. and Eric Van Wincoop (2003) "Gravity and Gravitas: A Solution to the Border Puzzle” American Economic Review 93(1), 170-192.

Baldwin, Richard and Daria Taglioni (2007) “Trade Effects of the Euro” Journal of Economic Integration 22(4), 780-818.

Baldwin, Richard, Virginia Di Nino, Lionel Fontagné, Robert De Santis, and Daria Taglioni (2008) "Study on the Impact of the Euro on Trade and Foreign Direct Investment" European Economy Economic Papers 321.

Berger, Helge, and Volker Nitsch (2008) "Zooming Out: The Trade Effect of the Euro in Historical Perspective” Journal of International Money and Finance 27(8), 1244-126.

Baier, Scott, and Jeffrey Bergstrand (2009) “Bonus vetus OLS” Journal of International Economics 77, 77-85.

Baier, Scott, Jeffrey Bergstrand, Peter Egger, and Patrick McLaughlin (2008) “Do Economic Integration Agreements Actually Work? Issues in Understanding the Causes and Consequences of the Growth of Regionalism,” The World Economy 31 (4), 461-497.

Bun, Maurice and Franc Klaassen (2007) "The Euro Effect on Trade is not as Large as Commonly Thought” Oxford Bulletin of Economics and Statistics 69,473-96.

Bussière, Matthieu, Jarko Fidrmuc, and Bernd Schnatz (2005) "Trade Integration of Central and Eastern European Countries Lessons From A Gravity Model” European Central Bank, Working Paper Series, No. 545, November.

Carrere, Celine (2006). "Revisiting the Effects of Regional Trade Agreements on Trade Flows with Proper Specification of the Gravity Model” European Economic Review 50, 223-247

Eicher, Theo and Christian Henn (2011a) In Search of WTO Trade Effects: Preferential Trade Agreements Promote Trade Strongly, But Unevenly" Journal of International Economics 83, 137-153.

Gil, Salvador, Rafael Llorca, and J. Antonio Martínez-Serrano (2008) “Assessing the Enlargement and Deepening of the European Union,” World Economy, 1253-1272.

Glick, Reuven and Andrew K. Rose (2002) "Does a Currency Union Affect Trade? The TimeSeries Evidence” European Economic Review 46(6), 1125-51.

Glick, Reuven and Andrew K. Rose (2016) "Currency Unions and Trade: A Post-EMU Reassessment” European Economic Review 87, 78-91. 
Head, Keith and Thierry Mayer (2014) "Gravity Equations: Workhorse, Toolkit, and Cookbook” chapter 3 in Gopinath, G., E. Helpman, and K. Rogoff (eds), vol. 4 of the Handbook of International Economics (Elsevier, Amsterdam), 131-95.

Micco, Alejandro, Ernesto Stein, and Guillermo Ordonez (2003) "The Currency Union Effect on Trade: Early Evidence on EMU” Economic Policy 18, 315-36.

Rose, Andrew K. (2004) "Do We Really Know that the WTO Increases Trade?"American Economic Review 94 (1), 98-114.

Subramanian, Arvind and Shang-Jin Wei (2007) "The WTO Promotes Trade, Strongly but Unevenly" Journal of International Economics 72, 151-175. 
Table 1: Chronology of Membership in EU and EMU

\begin{tabular}{|c|c|c|c|c|}
\hline \multicolumn{2}{|c|}{$\underline{\text { Old Members }}$} & & \multicolumn{2}{|c|}{$\underline{\text { New Members }}$} \\
\hline $\begin{array}{l}\text { Joined } \\
\text { EU }\end{array}$ & $\begin{array}{c}\text { Joined } \\
\text { EMU }\end{array}$ & & $\begin{array}{c}\text { Joined } \\
\text { EU }\end{array}$ & $\begin{array}{c}\text { Joined } \\
\text { EMU }\end{array}$ \\
\hline 1958 & 1999 & Slovenia & 2004 & 2007 \\
\hline 1958 & 1999 & Cyprus & 2004 & 2008 \\
\hline 1958 & 1999 & Malta & 2004 & 2008 \\
\hline 1958 & 1999 & Slovakia & 2004 & 2009 \\
\hline 1958 & 1999 & Estonia & 2004 & 2011 \\
\hline 1951 & 1999 & Latvia & 2004 & 2014 \\
\hline 1973 & 1999 & Lithuania & 2004 & 2015 \\
\hline 1973 & & Czech Rep. & 2004 & \\
\hline 1973 & & Poland & 2004 & \\
\hline 1981 & 2001 & Hungary & 2004 & \\
\hline 1986 & 1999 & Romania & 2007 & \\
\hline 1986 & 1999 & Bulgaria & 2007 & \\
\hline 1995 & 1999 & Croatia & 2013 & \\
\hline 1995 & 1999 & & & \\
\hline 1995 & & & & \\
\hline
\end{tabular}


Table 2: Panel Gravity Estimates for Bilateral Exports

\begin{tabular}{|c|c|c|c|c|}
\hline & \multicolumn{2}{|c|}{ Pooled LS } & \multicolumn{2}{|c|}{ Pair Fixed Effects } \\
\hline & (1) & (2) & (3) & (4) \\
\hline & All CUs & Disagg. EMU & All CUs & Disagg. EMU \\
\hline $\begin{array}{l}\text { All Currency } \\
\text { Unions }\end{array}$ & $\begin{array}{l}.90 \\
(.08)\end{array}$ & & $\begin{array}{c}.61 \\
(.05)\end{array}$ & \\
\hline $\begin{array}{l}\text { Non-EMU } \\
\text { Currency Union }\end{array}$ & & $\begin{array}{l}1.07 \\
(.10)\end{array}$ & & $\begin{array}{c}.71 \\
(.09)\end{array}$ \\
\hline EMU & & $\begin{array}{l}.19 \\
(.07)\end{array}$ & & $\begin{array}{l}.46 \\
(.05)\end{array}$ \\
\hline $\begin{array}{l}\text { All Regional Trade } \\
\text { Agreements }\end{array}$ & $\begin{array}{l}1.00 \\
(.03) \\
\end{array}$ & $\begin{array}{l}1.03 \\
(.04)\end{array}$ & $\begin{array}{c}.37 \\
(.02)\end{array}$ & $\begin{array}{l}.38 \\
(.03)\end{array}$ \\
\hline $\begin{array}{l}\text { Log } \\
\text { Distance }\end{array}$ & $\begin{array}{l}-1.03 \\
(.02)\end{array}$ & $\begin{array}{r}-1.03 \\
(.02) \\
\end{array}$ & .. & .. \\
\hline $\begin{array}{l}\text { Log Product } \\
\text { Real GDPs }\end{array}$ & $\begin{array}{l}1.04 \\
(.01)\end{array}$ & $\begin{array}{l}1.05 \\
(.01)\end{array}$ & $\begin{array}{l}.77 \\
(.03)\end{array}$ & $\begin{array}{l}.76 \\
(.03)\end{array}$ \\
\hline $\begin{array}{l}\text { Log Product } \\
\text { Real GDP/capita }\end{array}$ & $\begin{array}{l}.12 \\
(.01)\end{array}$ & $\begin{array}{l}.12 \\
(.01)\end{array}$ & $\begin{array}{l}.43 \\
(.03)\end{array}$ & $\begin{array}{l}.44 \\
(.03)\end{array}$ \\
\hline Common Language & $\begin{array}{l}.51 \\
(.03)\end{array}$ & $\begin{array}{l}.50 \\
(.03)\end{array}$ & .. & .. \\
\hline $\begin{array}{l}\text { Common Land } \\
\text { Border }\end{array}$ & $\begin{array}{c}.76 \\
(.08) \\
\end{array}$ & $\begin{array}{l}.76 \\
(.08) \\
\end{array}$ & .. & .. \\
\hline Common Colonizer & $\begin{array}{l}.66 \\
(.05)\end{array}$ & $\begin{array}{l}.64 \\
(.05)\end{array}$ & .. & .. \\
\hline $\begin{array}{l}\text { Current } \\
\text { Colony }\end{array}$ & $\begin{array}{l}.95 \\
(.19)\end{array}$ & $\begin{array}{l}.89 \\
(.19)\end{array}$ & $\begin{array}{l}.50 \\
(.17)\end{array}$ & $\begin{array}{c}.47 \\
(.17)\end{array}$ \\
\hline $\begin{array}{l}\text { Ever } \\
\text { Colony }\end{array}$ & $\begin{array}{l}1.30 \\
(.10)\end{array}$ & $\begin{array}{l}1.30 \\
(.10)\end{array}$ & .. & .. \\
\hline $\begin{array}{l}\text { Same } \\
\text { Nation }\end{array}$ & $\begin{array}{l}-1.35 \\
(.62)\end{array}$ & $\begin{array}{r}-1.32 \\
(.62)\end{array}$ & .. & .. \\
\hline $\mathbf{R}^{2}$ & .61 & .61 & .49 & .49 \\
\hline
\end{tabular}

Regressand: log of bilateral exports. Intercept, year controls, product of national land masses, and dummy variables for the number of landlocked and island countries in the pair, not reported. 28,114 fixed dyadic (pair-specific) effects included in the last three col. not reported. Standard errors robust to dyadic clustering recorded in parentheses. ".." indicates not available. Annual data for $>200$ countries. 740,900 observations, 1948-2013. 
Table 3: Panel Gravity Estimates for Bilateral Exports with Country-year Effects

\begin{tabular}{|c|c|c|c|c|}
\hline & \multicolumn{2}{|c|}{$\begin{array}{c}\text { Exporter } \mathrm{x} \text { year, } \\
\text { Importer } \mathrm{x} \text { year effects }\end{array}$} & \multicolumn{2}{|c|}{$\begin{array}{l}\text { Exporter x year, } \\
\text { Importer x year, } \\
\text { dyadic fixed effects }\end{array}$} \\
\hline & (1) & $(2)$ & (3) & (4) \\
\hline & All CUs & Disagg. EMU & All CUs & Disagg. EMU \\
\hline All Currency Unions & $\begin{array}{c}.51 \\
(.02) \\
\end{array}$ & & $\begin{array}{c}.34 \\
(.02) \\
\end{array}$ & \\
\hline $\begin{array}{l}\text { Non-EMU Currency } \\
\text { Union }\end{array}$ & & $\begin{array}{c}.76 \\
(.02) \\
\end{array}$ & & $\begin{array}{l}.30 \\
(.03) \\
\end{array}$ \\
\hline EMU & & $\begin{array}{l}-.65 \\
(.03) \\
\end{array}$ & & $\begin{array}{c}.43 \\
(.02) \\
\end{array}$ \\
\hline $\begin{array}{l}\text { All Regional Trade } \\
\text { Agreements }\end{array}$ & $\begin{array}{c}.57 \\
(.01)\end{array}$ & $\begin{array}{c}.60 \\
(.01)\end{array}$ & $\begin{array}{c}.39 \\
(.01)\end{array}$ & $\begin{array}{c}.39 \\
(.01)\end{array}$ \\
\hline $\begin{array}{l}\text { Log } \\
\text { Distance }\end{array}$ & $\begin{array}{l}-1.36 \\
(.003) \\
\end{array}$ & $\begin{array}{l}-1.36 \\
(.003) \\
\end{array}$ & .. & .. \\
\hline Common Language & $\begin{array}{c}.36 \\
(.01)\end{array}$ & $\begin{array}{c}.35 \\
(.01)\end{array}$ & .. &. \\
\hline $\begin{array}{l}\text { Common Land } \\
\text { Border }\end{array}$ & $\begin{array}{c}.33 \\
(.01) \\
\end{array}$ & $\begin{array}{c}.33 \\
(.01) \\
\end{array}$ & .. & .. \\
\hline Common Colonizer & $\begin{array}{c}.83 \\
(.01) \\
\end{array}$ & $\begin{array}{c}.81 \\
(.01) \\
\end{array}$ & .. & .. \\
\hline $\begin{array}{l}\text { Current } \\
\text { Colony }\end{array}$ & $\begin{array}{c}.87 \\
(.04) \\
\end{array}$ & $\begin{array}{c}.80 \\
(.04) \\
\end{array}$ & $\begin{array}{c}.26 \\
(.03) \\
\end{array}$ & $\begin{array}{c}.27 \\
(.03) \\
\end{array}$ \\
\hline $\begin{array}{l}\text { Ever } \\
\text { Colony }\end{array}$ & $\begin{array}{l}1.39 \\
(.01) \\
\end{array}$ & $\begin{array}{l}1.38 \\
(.01) \\
\end{array}$ & .. & .. \\
\hline $\begin{array}{l}\text { Same } \\
\text { Nation }\end{array}$ & $\begin{array}{c}.05 \\
(.06)\end{array}$ & $\begin{array}{l}-.01 \\
(.06)\end{array}$ & .. & .. \\
\hline $\mathbf{R}^{2}$ & .72 & .72 & .86 & .86 \\
\hline
\end{tabular}

Regressand: log of bilateral exports. 22,438 exporter-year and importer-year controls included not reported. 33,866 fixed dyadic (pair-specific) effects included in col. 3 and 4 not reported. Robust standard errors recorded in parentheses. ".." indicates not available. 879,794 annual observations data for $>200$ countries, 1948-2013. 
Table 4: Panel Gravity Estimates of EMU and EU for Bilateral Exports

\begin{tabular}{|c|c|c|c|c|}
\hline & Pooled LS & $\begin{array}{l}\text { Pair Fixed } \\
\text { effects }\end{array}$ & $\begin{array}{c}\text { Exporter } \mathrm{x} \text { year, } \\
\text { Importer } \mathrm{x} \text { year } \\
\text { effects }\end{array}$ & $\begin{array}{l}\text { Exporter x year, } \\
\text { Importer x year, } \\
\text { dyadic fixed } \\
\text { effects }\end{array}$ \\
\hline & $(1)$ & $(2)$ & (3) & (4) \\
\hline & $\begin{array}{l}\text { Disagg. } \\
\text { EMU\&EU }\end{array}$ & $\begin{array}{l}\text { Disagg. } \\
\text { EMU\&EU }\end{array}$ & $\begin{array}{l}\text { Disagg. } \\
\text { EMU\&EU }\end{array}$ & $\begin{array}{l}\text { Disagg. } \\
\text { EMU\&EU }\end{array}$ \\
\hline $\begin{array}{l}\text { Non-EMU } \\
\text { Currency Union }\end{array}$ & $\begin{array}{l}1.07 \\
(.10) \\
\end{array}$ & $\begin{array}{c}.72 \\
(.09) \\
\end{array}$ & $\begin{array}{c}.75 \\
(.02) \\
\end{array}$ & $\begin{array}{c}.30 \\
(.03) \\
\end{array}$ \\
\hline EMU & $\begin{array}{c}.15 \\
(.07) \\
\end{array}$ & $\begin{array}{c}.15 \\
(.04) \\
\end{array}$ & $\begin{array}{l}-.14 \\
(.04) \\
\end{array}$ & $\begin{array}{c}.11 \\
(.04)\end{array}$ \\
\hline Non-EU RTA & $\begin{array}{l}1.02 \\
(.04) \\
\end{array}$ & $\begin{array}{c}.29 \\
(.03) \\
\end{array}$ & $\begin{array}{c}.71 \\
(.01) \\
\end{array}$ & $\begin{array}{c}.30 \\
(.01) \\
\end{array}$ \\
\hline EU & $\begin{array}{l}1.08 \\
(.06) \\
\end{array}$ & $\begin{array}{c}.86 \\
(.03) \\
\end{array}$ & $\begin{array}{c}.01 \\
(.02) \\
\end{array}$ & $\begin{array}{c}.94 \\
(.02) \\
\end{array}$ \\
\hline $\begin{array}{l}\text { Log } \\
\text { Distance }\end{array}$ & $\begin{array}{r}-1.02 \\
(.02) \\
\end{array}$ &.. & $\begin{array}{l}-1.36 \\
(.04)\end{array}$ &.. \\
\hline $\begin{array}{l}\text { Log Product } \\
\text { Real GDPs }\end{array}$ & $\begin{array}{l}1.05 \\
(.01) \\
\end{array}$ & $\begin{array}{c}.81 \\
(.03) \\
\end{array}$ & .. & .. \\
\hline $\begin{array}{l}\text { Log Product } \\
\text { Real GDP/capita }\end{array}$ & $\begin{array}{c}.12 \\
(.01)\end{array}$ & $\begin{array}{c}.39 \\
(.03)\end{array}$ & .. & .. \\
\hline $\begin{array}{l}\text { Common } \\
\text { Language }\end{array}$ & $\begin{array}{c}.50 \\
(.03) \\
\end{array}$ & .. & $\begin{array}{c}.35 \\
(.01) \\
\end{array}$ & .. \\
\hline $\begin{array}{l}\text { Common Land } \\
\text { Border }\end{array}$ & $\begin{array}{c}.76 \\
(.08) \\
\end{array}$ & .. & $\begin{array}{c}.33 \\
(.01) \\
\end{array}$ & .. \\
\hline $\begin{array}{l}\text { Common } \\
\text { Colonizer }\end{array}$ & $\begin{array}{c}.64 \\
(.05) \\
\end{array}$ & .. & $\begin{array}{c}.80 \\
(.01) \\
\end{array}$ & .. \\
\hline $\begin{array}{l}\text { Current } \\
\text { Colony }\end{array}$ & $\begin{array}{c}.89 \\
(.19) \\
\end{array}$ & $\begin{array}{c}.45 \\
(.17) \\
\end{array}$ & $\begin{array}{c}.82 \\
(.06)\end{array}$ & $\begin{array}{c}.24 \\
(.05)\end{array}$ \\
\hline $\begin{array}{l}\text { Ever } \\
\text { Colony }\end{array}$ & $\begin{array}{l}1.30 \\
(.10) \\
\end{array}$ & .. & $\begin{array}{l}1.36 \\
(.02) \\
\end{array}$ & .. \\
\hline $\begin{array}{l}\text { Same } \\
\text { Nation }\end{array}$ & $\begin{array}{r}-1.32 \\
(.62) \\
\end{array}$ & .. & $\begin{array}{c}.06 \\
(.08)\end{array}$ & .. \\
\hline $\mathbf{R}^{\mathbf{2}}$ & $.61 ?$ & .50 & .72 & .86 \\
\hline
\end{tabular}

Regressand: log of bilateral exports. Intercept, year controls, product of national land masses, and dummy variables for the number of landlocked and island countries in the pair, not reported. 28,114 fixed dyadic (pairspecific) effects included in the col. (2), (4) not reported. Standard errors robust to dyadic clustering recorded in parentheses. ".." indicates not available. Annual data for $>200$ countries. 740,900 observations in col. (1), (2), 879,794 in col. (3), (4), 1948-2013. 
Table 5: Panel Gravity Estimates for Bilateral Exports: Old vs. New Members

\begin{tabular}{|c|c|c|c|}
\hline & \multicolumn{3}{|c|}{$\begin{array}{c}\text { Exporter } x \text { year, } \\
\text { Importer } \mathrm{x} \text { year, dyadic fixed effects }\end{array}$} \\
\hline & (1) & (2) & (3) \\
\hline Sample: & $\begin{array}{c}\text { EMU } \\
\text { and } \\
\text { EU }\end{array}$ & $\begin{array}{c}\text { EMU Dis-agg } \\
\text { and } \\
\text { EU }\end{array}$ & $\begin{array}{c}\text { EMU Dis-agg. } \\
\text { and } \\
\text { EU Dis-agg. }\end{array}$ \\
\hline $\begin{array}{l}\text { Non-EMU } \\
\text { Currency Unions }\end{array}$ & $\begin{array}{l}.30 \\
(.03) \\
\end{array}$ & $\begin{array}{l}.30 \\
(.03)\end{array}$ & $\begin{array}{c}.30 \\
(.03)\end{array}$ \\
\hline EMU & $\begin{array}{c}.11 \\
(.02) \\
\end{array}$ & & \\
\hline Old-Old EMU & & $\begin{array}{l}.07 \\
(.02)\end{array}$ & $\begin{array}{c}.34 \\
(.02)\end{array}$ \\
\hline New EMU & & $\begin{array}{c}.24 \\
(.11) \\
\end{array}$ & $\begin{array}{l}-.05 \\
(.04)\end{array}$ \\
\hline Non-EU RTAs & $\begin{array}{c}.30 \\
(.01) \\
\end{array}$ & $\begin{array}{c}.30 \\
(.01) \\
\end{array}$ & $\begin{array}{c}.31 \\
(.01)\end{array}$ \\
\hline EU & $\begin{array}{c}.94 \\
(.02) \\
\end{array}$ & $\begin{array}{c}.93 \\
(.01)\end{array}$ & \\
\hline Old-Old EU & & & $\begin{array}{c}.52 \\
(.01)\end{array}$ \\
\hline New EMU & & & $\begin{array}{l}1.36 \\
(.02)\end{array}$ \\
\hline $\mathbf{R}^{2}$ & .86 & .86 & .85 \\
\hline
\end{tabular}

Regressand: log of bilateral exports. Regressors included but not reported: current colony, dummies for French Departments included in EMU and EU pairs. 22,438 exporter-year and importer-year controls and 33,866 fixed dyadic (pair-specific) effects included not reported. Robust standard errors recorded in parentheses. 879,794 annual observations data for $>200$ countries, 1948-2013. 